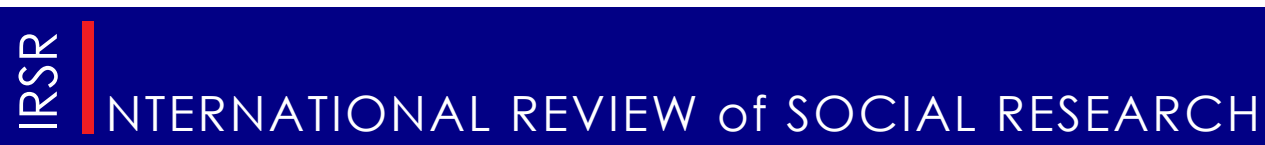

Volume 1, Issue 2, June 2011, 85-98

International Review of Social Research

\title{
Orange or Pink? Colours, Houses and Modernity in Rural Romania
}

\author{
Monica IANCĂU* \\ National School of Political and Administrate Sciences
}

\begin{abstract}
The saturated flashy colors used in exterior paintings of houses in the Romanian rural environment represent a discussion topic for on-lookers, whether they are local inhabitants, tourists or specialists interested in urban planning. The same colors are perceived differently and express different significances, denoting more than mere chromatic nuances. What are these significances and what role do they play in inter-human relationships? I have tried to answer this question by analyzing the interviews gathered in the summers of 2008 and 2009 in two touristic areas, Ghețari Plateau (Apuseni Mountains) and Apuseni Mountains (Bukovina). The results point to identity-defining elements shown by the owners of these houses in terms of aspirations towards modernity and the spectacular. They wish to escape the label of 'provincial' and to be connected to the 'global world'. Alternatively, many tourists are disappointed by the widespread usage of these colors in almost all the regions of the country and consider that as a process of homogenization, which erases local specific traits that one would expect to see in these areas.
\end{abstract}

Keywords: saturated flashy colours, housing, spectacular, modernity, homogenization

\section{Introduction}

My interest for the subject of house colours stems from two field research were carried out in an interdisciplinary manner by architects, urban planners, landscape artists, specialists in ethnography, geography, sociology, and anthropology gathered under the tutelage of the Order of Architects in Romania (OAR). The recurrent theme established by the OAR involves describing and explaining the passing of the Romanian rural building space from traditional to modern, with the definite aim of saving and revitalizing the realm of traditional architecture. As the effort of describing the changes that occurred with the passage of time could be rendered in a much accurate manner by the more technical colleagues who worked on the field, I

email: monica.iancau@yahoo.com. Beneficiary of the project called 'Doctoral scholarships for the development of the knowledge-based society,' co-funded by the European Union through the European Social Fund, Sectorial Operational Programme Human Resources Development 2007-2013. 
have focused, together with my fellow team workers (sociologist Simona Branişte and anthropologist Camelia Butuligă) on understanding the perspective of the local people on the changes in the household and, not least, on the perspective of the tourists, who have influenced part of these changes.

Considering this framework, I deemed it a challenge to attempt to encompass the whole string of changes in the analysis of a single detail of inhabiting. On the other hand, I was surprised by the intensity and variety of feelings witnessed during the interviews in connection with the colours selected for painting the exterior structures, which made me wonder how it came to be that people regarded the same colours so differently. Can colours reflect more than nuances, can they tell us something about inhabiting a space and daily life? Those who favour these saturated flashy colours seem to direct their aspirations towards ordinary widespread values of a spectacular modernity, while those who criticize these colours aspire to identify with values of a harmonious past.

Why two case studies and not only one? I have chosen to use both research works done on this material in order to point to the amazing similarities found in two different parts of the country. In fact, the saturated flashy colours are widespread almost throughout the country, which, one may claim, leads to the homogenization of the landscape. This homogenization is noticed both by tourists and the specialists who would rather have this phenomenon stopped.. The problem is nevertheless beyond control, since specialists admit that they have no way of working for the benefit of the rural inhabitants, because the latter cannot afford to pay professional consultants. Furthermore, the local administration lacks the competence to defend the provisions of a General Urban Plan in the absence of understanding of the provisions stipulated in such a document. Quite often, the local administration employees themselves choose the same flashy colours to paint their houses or the building of the town hall. The only forms through which the architects adopt a position are the cultural projects attempting to educate the taste of the population.

\section{Fieldwork Site and Data Gathering}

The Ghețari plateau belongs to the natural park of Apuseni and comprises the villages of Ghețari (37 households), Ocoale (92 households), Munună (28 households), and Hănăşeşti (32 households), totaling 595 inhabitants. Administratively, these five villages are included in the commune of Gârda de Sus, and are catalogued as scattered villages situated at some of the highest altitudes inhabited in the country, more precisely at approximately $1,200 \mathrm{~m}$. At present, the local people, known as under the name of 'moți', earn their living from exploiting and selling unprocessed timber, raising cattle, migration of youth to western countries and tourist lodging services. Tourism in the Ghetari plateau, if we are to consider the stages of development put forth by Noronha (apud Cohen, 1984: 383 , i.e. discovery, then local initiatives, followed by institutionalization), is currently undergoing a stage of discovery. This is despite the fact a nearby famous cave (Scărişoara) has 
been a great attraction of the Apuseni region. The stage of local reaction is in an incipient phase, as in 2008 there existed only two boarding houses.

The other fieldwork site is located in North-Eastern Romania. The commune centre, called Mănăstirea Humorului, is much bigger, since it boasts more than 2,500 inhabitants. The economic activities carried out here are similar to those met in the other fieldwork site, but tourism is much more developed. The main attraction of the locality is the monastery itself, a monument included in the UNESCO heritage list, which enabled the locality to enter a phase of institutionalization of tourism. There are no hotel chains as of yet, but investors from Gura Humorului, Suceava, Bucharest, and even from abroad have shown an interest to do business here (one of the foremost boarding houses is owned by an Italian businessman).

Research Methods. We have used the samemethods in both studies: biography of houses and photo interviewing (11 photos with new or old houses and boarding houses from the locality and from the region neighbouring the locality, in the interviews taken in the Apuseni Mountains, 15 photos from the interviews taken in Bucovina respectively). Six of the interviews were individual, 11 group interviews, two focus groups in Apuseni, four individual and 12 group interviews in Bucovina. My own personal observations, along with the information shared within the interdisciplinary group, the simple conversations I had with the local people with whom I have interacted more often (hosts, kitchen maids), and the feedback received from local inhabitants during public presentations
I held in the church or in the school have rounded up the overall range of problems. The presentations delivered at the end of the research work in both localities, to which as many local inhabitants as possible were invited to participate, were extremely useful. Their reactions of approval or disapproval emphasized some of the ideas presented here.

Persons questioned in Apuseni. The total number of tourists interviewed was 41 , while the number of local inhabitants was 16 . Among the tourists 29 were Romanians and 12 foreign citizens (two Belgians, two Germans, one American, five Poles, one Frenchman, and one Italian). As for the gender dimension, the interviewees were divided into eight men, thirteen women, their age varying between 18 and 55. Among the interviews with the local people, 13 women and six men were recorded, aged between 14 and 86 years old.

Persons investigated in Bucovina. The total number of tourists interviewed is 21 , while the number of local inhabitants is 20 . The tourists were 14 Romanian and seven foreigners (three Dutch, three Germans, and one Spanish), eight men and 13 women, aged between 18 and 55 years. Locals were 13 women and seven men between 14 and 86 years.

\section{Results}

Several categories of answers have been outlined in both regions, and the preferences exhibited a surprising tendency for reiteration. On the whole, it may be stated that most of the interviewed tourists preferred the 
models of traditional houses from among the set of photographs (please see Photo 1 and Photo 3), while most of the local inhabitants preferred models of houses built recently (Photo 2 and Photo 4). The traditional houses preferred by tourists is painted in wood-

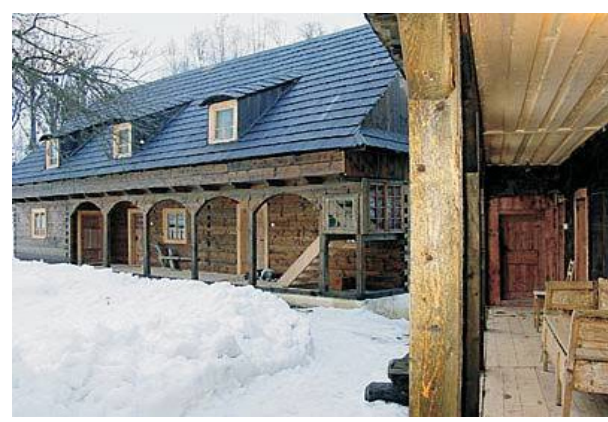

Photo 1. Apuseni tourists preferred this photo

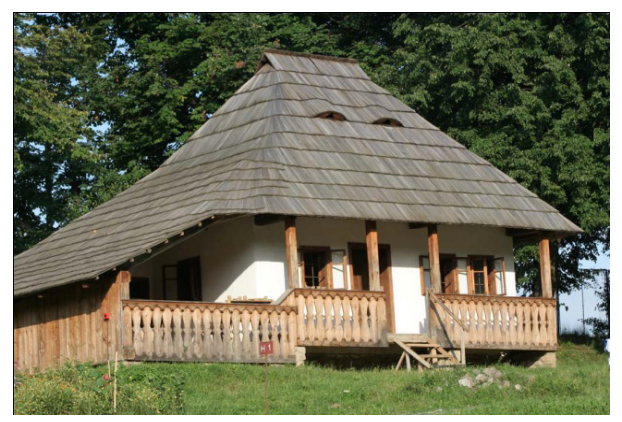

Photo 3. Bucovina tourists and local elderly inhabitants preferred this photo

How can the difference between tourists and local inhabitants be explained? What about the similarities among the tourists and the similarities among local inhabitants? The comments made concerning the vivid colors of houses erected at the beginning of the 21 st century serve as an initial answer. First, I shall talk about the vision of tourists and then I shall examine the vision of the local inhabitants in some colour or in white, with a wooden porch and shingle roof. The modern house chosen by local inhabitants has one floor and attic, and is painted orange. The photos below illustrate these preferences very clearly:

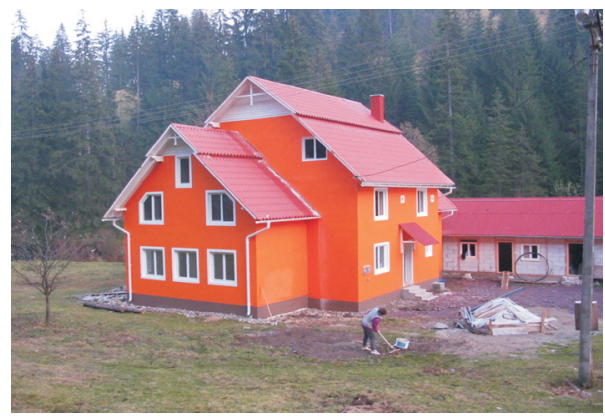

Photo 2. Apuseni local inhabitants preferred this photo

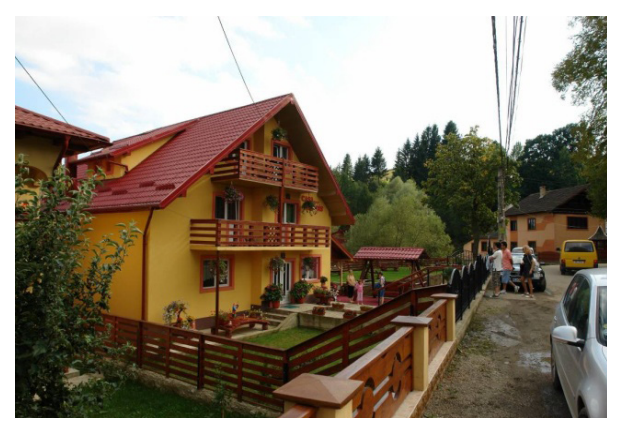

Photo 4. Young and middle aged local inhabitants chose this photo

short sections.

Tourists. Most of these consider flashy colours as unsuitable in the two researched areas. The keywords that occur in their interviews were: kitsch, exaggerated gaudiness, plastic, artificial, hypermodern, bad taste. For them, these colours signify the loss of the local specific character and the passing to the homogenization trend in the Romanian rural landscape. 
In order to explain the visual effect of flashy colours, tourists mention that these are tiring, 'they make your eyes hurt,' and 'you can't watch them too long.' A part of the young foreign tourists are confused, stating that they do not understand the 'contradiction' between the flashy colours and the rest of the landscape (farming activities, horse-drawn carts, hay stacks, etc.). Other young Romanian tourists draw inferences on the education and income of the owners: 'you're a school dropout and you wanna show off with your wealth.' Middle-aged tourists are sad and angry and consider that the motivation behind preferring these colours is a misplaced modernity.

For exterior paintings, tourists would like to see colours like white, cream, beige, brown, and not yellow, orange, pink, red, green or blue. As for the houses built of wood, they prefer them to stay un-plastered and not painted, because according to them the colour of wood looks better more pleasant than any painting. In their opinion, the solution to solving these problems is that the law should forbid the use of these colours, since the process of educating people takes too much time.

The traditional house is described as being a place which makes you feel good and forget about pressing worries, it is 'small, intimate, has a personality, I'd feel it was mine if I lodged there.' By contrast, the coloured houses make tourists desire to stick to the transitory status, passing through the respective areas just in order to visit certain sights. Flashy colours are also associated with other elements considered not to be specific to the rural environment, such as concrete/plastic/insulated window frames/marble/balusters/stainless steel/ grit stone/faience/lawn.

Two tourists from Eastern Germany acknowledge the situation of flashy colours as an experience they also went through after the fall of the Berlin wall. The selection of these colours seems to belong to a movement of retrieving a modernity which the citizens had previously been denied access to. The form of exaggerated spectacular nature might be explained by the considerable differences existing between the economic offers during the communist vs. the capitalist period, by the shortages vs. abundance on the market in the two historical periods of these countries.

Elderly Local Inhabitants. These disapprove of the strident colours used by the generation of their children and grandchildren, because they think the latter do not build 'a house that's bound to last a lifetime,' but 'will keep themselves busy as long as they live,' and instead prefer to build hastily without a well-thought and unitary blueprint. The causes identified by them are the lack of time of reflection on a long-lasting plan and the imitation of unsuitable models - 'I told him he used a colour only Gypsies like.' They empathize with the problem of the importance of the aspect which they themselves are sensitive to, but consider themselves much more receptive to exterior criticism compared to younger generations. A 70-year old woman from Bucovina told us she intended to put plastic panelling on her house, but later changed her mind when someone told her 'not to let the devil make me ruin the house.'

Middle-aged and Young Local Inhabitants. The main model of inspiration indicated is the so-called 
modernity, illustrated by a variety of elements, such as the national journals specialized in the arrangement of the domestic space (Casa mea, Practic), the urban landscape and the successful tourist resorts in the country (Valea Prahovei, Arieşeni in Apuseni, Vatra Dornei in Bucovina). Western Europe is not mentioned as a model of inspiration for the selected colours, and migration to countries in the West does not seem to have exerted a direct influence on this dimension.

Besides the preoccupation to be modern, local inhabitants lay special stress on the neat aspect of houses, which for them is one way of saying they want the house to be beautiful. Because exterior paintings of houses exhibiting flashy colours are recent, these look neat and implicitly beautiful. This idea is explained by Vintilă Mihăilescu (2011) though the idea that villages in Romania have a moral order, in which the equivalence neat - beatiful advances towards a certain sacred character and is opposed to filth, ugliness and the profane. Thus, we deal with the 'eye of the female householder' in problems of urban planning.

The preferred house seems to be a building with one floor, an attic, should be painted orange, should have insulated window aluminium or PVC frames and the yard should look like a park. Those who choose other flashy colours, like pink, yellow, green, blue or violet want their house to be different from the houses painted in orange, which is the most widespread colour. In the case of active local inhabitants, the keywords that refer to these colours are: modern, neat, softened, brilliant, and diverse.

A big difference between the two studied regions is the perception of the traditional home. In Apuseni, the traditional home is associated with poverty, while in Bucovina it is associated with the idea of a museum. In other words, in the first case the urban realm is considered as superior on a course of evolution from dearth to wealth, while in the second case it links past to future, with the past remaining the realm of museums, to which one owes respect, sentimental attachment, but which however in their opinion is out of time. Thus, the urban and the modern are considered as belonging to the present and to the future.

Colours and Tourist - Locals Relationships. In Bucovina, where tourism is more widely developed, local inhabitants who own flashycoloured houses have acknowledged not only the 'traditional' preferences of their tourists, but also the fact that the investors who have financed the building of houses in accordance with this requirement stand to gain much more money than they would otherwise. In order to solve the cognitive dissonance resulting from the relationship tourist-host, local entrepreneurial inhabitants declare that they would like to build, apart from the 'modern' home, an additional 'traditional' dwelling that looks old, displays the status of a 'museum', and plays the role of tourist attraction, just like folk dance bands, folklore costumes and the eggs painted for Easter. They express the regret for not having kept their old houses and for having ruined or changed them in the last 20 years. In this respect, they try to incorporate certain traditional objects in their houses or transform certain outbuildings into places worth visiting. 
For instance, some people have given up raising cattle and transformed their stable into such a place, exhibiting a series of traditional objects for tourists to see.

The common denominator of the local inhabitants and the tourists is the fact that they all agree with the idea of a combination between traditionalism and modernity. The difference between them is first grasped in the debate over the possible combinations. Tourists want to find traditional houses with but a few modern elements that make life easier and bring more comfort (toilet, modernized kitchen, TV set, telephone and Internet), while the local inhabitants build modern homes with traditional insertions.

Colours of Houses and the Feminine Gender. Another idea stemming from the analysis of data is that women are more involved in decision-making regarding the selection of colours, while men focus more on the technical part of building a house. In the absence of funds that would allow them to hire specialists, most of the interviewed families build their houses on their own, using local specialists only for more difficult tasks, such as the building of the roof. The division of labour within the family would accordingly suggest that the woman of the family assumes the role of 'architect' and the man that of 'building engineer.'

Dynamics of Colours in Exterior Paintings. It has been suggested during interviews that there may exist an evolution in the intensity of the selected colours, with an initial preference for deep pink, red, yellow, and orange, after which pink and red disappear and yellow and orange retain a lighter shade. This is one way of explaining the difference of the intensity of orange present in the two photos illustrated above, with the locality of Mănăstirea Humorului being in stage II and the Ghețari plateau in stage I. At the beginning of the 2000's, these colours were also used in Bucovina, but after 5 or 6 years the new constructions were painted in lighter colours.

A few years after the building of the house or of certain parts of it, local inhabitants end up regretting the fact that they invested their money in something that is no longer the newest fashion or the most recent trend. In the case of constructions, the disapproval expressed by other people causes considerable frustration, since financially speaking it is difficult to modify that which they regret. Owners of boarding houses who find themselves in this situation try to compensate by delivering top-quality services at prices lower than those offered by owners of the trendiest boarding houses.

But how can we explain the decrease of the popularity of these colours, the regret caused by their use and the switching to lighter intensities? A couple of tourists from Bucharest resort to an explanation that stems from their own experience: 'We bought kitchen furniture that is coloured raw green. When our guests visit us, they all say: 'Wow, your furniture looks great!' but we answer them: 'Yeah, we know that, but that's only at first, when you set eyes on it, but you get to hate it once you get used to it.' The initial attractiveness, followed by ulterior visual fatigue, suggests that in future we may witness a decline and disappearance in the use of spectacular paintings in the case of 
dwellings, and later on locals will use them only for buildings where people are in transit. This idea is also backed by the tourists from Eastern Germany I came in contact with. In their region of origin, the painting of buildings in deep nuances lasted for a few years and afterwards this problem disappeared altogether (it is likely that the reason people gave up using flashy colours faster than in this country is also identifiable in the legal constraints in force there).

Is it perhaps true that the use of these colours represents but a stage of ordinary daily life and some people have lived this period during childhood (room, toys, gaudy-coloured clothes), others during adolescence, while owners of coloured homes did not get to share in this use of deep colours in the past and when they became grown-ups they reached a point where they want to experiment it? In this sense, we may say that the age of experimentation with the saturated colours influences the quantity of their use during adulthood. Most of the interviewed tourists use them only in order to 'lay stress' on the decoration of their homes, while a part of the local inhabitants have chosen them as principal background in exterior and/or interior paintings. As a consequence, it is not the flashy saturated colours themselves but their quantity that is the key differentiating the pro and con respondents.

Artists and architects agree only partially with this hypothesis. If many children gradually reduce the quantity of saturated colours within their space, it is with the assistance of their parents that they do this, as it is their parents who lend a hand in the process of educating the children's taste. They consider this difference of quantity a problem of aesthetics and of honing their tastes, a process difficult to accomplish in a short time. In their opinion, reaching beauty needs painstaking efforts. It is precisely because of this that they regret so deeply the giving up of traditional art, which reflects the efforts made by people in the course of hundreds of years. It was replaced in a matter of decades by the mass consumerism specific to modernity, and we may probably look at another couple of centuries of refining of tastes before we again reach that lost 'good taste.'

Law and Colour. The regulations included in the General Urbanism Plan of the two studied regions stipulate the outlawing of flashy colours and the selection of a range of colours long used in those places. In the construction guide printed for the people living on the Ghețari plateau, the urban architect points out that 'the natural colour of wood shall be preserved... the use of strident colours is forbidden; the paintings will done in white or blue; the ground-floor plaster will be painted white.' (OAR - Transylvania branch, $2009,40)$. The roof is to be painted dark brown, like the colour of shingles (OAR - NE branch, 2011, 44). The answer the local inhabitants give when asked why these provisions are not respected is that they are not aware of them. In their opinion, it is a chaotic field that needs stricter rules.

\section{Discussions: Home Colours, Between Local and Global}

The cultural eye sees differently from the biological eye (Saunders, 2000, 
2007). The saturated flashy colours are appreciated as positive or negative by various social actors. The difference lies in the fact that putting these colours on the brickwork represents more than a chromatic nuance. They illustrate the aspirations of owners and of visitors. Judging by them, the tourists make conjectures linked to the educational and economic level of their hosts, but also regarding the price of lodging. In other words, colours offer identity to the inhabitants and tourists who drop by, and play an important role in interhuman relationships.

Concerning the identity and aspirations of the tourists encountered in the two areas of our research, the problem has been discussed in the anthropology of tourism literature, which has proved that these tourists are modern pilgrims, in search of authenticity, in search of a past associated with nature and with an eco living style that is sacred for them. Acknowledging their state, every now and again these tourists try to flee the shallowness and alienation of the modern man, finding lessdeveloped places where a simpler way of life still reigns supreme (Stronza, 2001; Mihăilescu, 2005; Cawley and Gillmor, 2008; Buckley, Ollenburg and Linsheng, 2008; Benthall, 1988). Once they reach the Ghețari plateau or the locality named Mănăstirea Humorului, they come face to face with a combination of contradictory elements, a mixture of traditionalism and modernity that pleases and disappoints them at the same time. The interesting thing is that the tourists mentioned in both studied cases the fact that the number of intenselycoloured buildings is rather badly represented in comparison with other regions in the country. However, they perceive a process of homogenization of the Romanian rural environment in the presence of these colours.

Local owners of coloured homes and boarding houses aspire to modernity in the way this notion is presented by certain magazines and TV channels, wishing to keep up with the spectacular character seen in urban environments. In this sense, they attempt to get rid of the label of 'provincial,' which points to something inferior, something that belongs to the past and must therefore be left to museums. They have acknowledged that their tourists are looking for that past, but wish to revitalize it only for the tourists to have some fun, not in order to adopt it in their own way of life. They consider the more severe tourists, who openly criticize their flashy coloured homes as hypocrites, because they belong to the urban world and very likely lead a daily life of consumerism, at the same time absurdly demanding of their hosts to stick to the past. On the other hand, what some people call a process of homogenization is for them a process of connecting to the exterior world. Thus, the saturated colours of homes fulfil a role of signalling that they are owned by young, dynamic, modern persons, who are connected to the world beyond the village.

What is the explanation given by other researchers for these social changes? In literature there is the idea that we deal with a passing state from static to dynamic, from a limited to an unlimited space, from men 'with roots' to people 'on the move,' from the feeling of belonging to the sentiment of getting connected to global processes. 
The author Manuel Castells (2010 [1996]: 453) shows that the world passes from space of places to space of flows, from localization to globalization. Edward Relph, Marc Augé, and George Ritzer are some of the authors preoccupied to conceptualize and explain the two opposing tendencies. Tourists are in search of 'places' that are authentic to the past, while local inhabitants are in search of 'non-places' of the present and future, where they feel connected to the world of globalization.

In his work entitled Place and Placelessness, geographer Edward Relph (1976: 45) points out that there exists a strong link between the identity of people and the identity of the places in which they live. He defines the identity of a place through the 'persistent sameness and unity which allows that [place] to be differentiated from others.' From the author's point of view, places can be authentic or non-authentic. An authentic place has the capacity to offer a sincere, non-hypocritical, genuine, and true experience. However, the modern world is headed for placelessness due to an absence of sensitivity towards the importance of places. The author identifies two causes: the kitsch, meaning the non-critical acceptance of mass values and the technique the preoccupation to be efficient as an ultimate end. Thus, communication and mass culture lead to the replacement of the diversity of many places in the world by anonymity and the option to change one place for another. Even if Relph states that placelessness is gaining ground against places, he nevertheless concludes that people cannot live without places, since these are a part of people's nature. Thus, in a word that underwent globalization, in which the local can no longer be isolated from the rest, it is necessary for us to reach a balance between local and global needs, between love for the local environment and belonging to it on the one hand, and the empathy and understanding of other places, on the other (Seamon and Sowers, 2008: 47).

Marc Augé (1997 [1995]: 2627) speaks about super-modernity in terms of excessive time and space, both instances of abundance being associated with technological production. Concerning the excess of space, Marc Augé refers to the possibility to reach any place on the planet (or outer space) in a matter of hours, to the circulation of information regarding other regions in the world and to a certain familiarity one feels towards places one has never been to before. He uses the dichotomy place - non-place, where the non-place represents the system of transportation (freeways, bus stations, airports, great commercial centres), but also any 'aestheticized, and at the same time desocialized and artificialized' places. To put it differently, the non-place is a 'a space that can not be defined as relational, historical, or concerned with identity' (idem: 77). It is a world in which people are born in clinics and die in hospitals, where the places of transit and temporary dwellings (hotel chains, camps of refugees, etc.) predominate, with a dense network of transportation, an unmediated and abstract commerce. These non-places do not create singular identities or relationships, but solely solitude and similitude. Places become rarer and rarer, like some shelters within 
non-places. The paradox of nonplaces is that they are considered by some people to be their home, as these people feel good in the anonymity of big shops, non-human services, and perpetual movement, idea that is developed also by Ritzer (2003 [2000]) using the concept 'velvet cage'.

Similarly, Anthony Giddens (2000 [1990]: 22-26) advances a theory of modernity around the concepts of emptying of time and of emptying of space, realities which originate in the appearance and dissemination of the wristwatch at the end of the 18th century.

George Ritzer (2010 [2007]: 88) takes up this dichotomy of place and non-place defined by Marc Augé and uses it in his theory about the globalization of nothing. To gauge the impact of globalization on places, the American sociologist proposes the use of the axis something-nothing. In his opinion, we deal with a shift of the world from something to nothing, from places with a distinctive character, with humanized and magic characteristics, to places that are generic, lack a distinctive character or are a-temporal, de-humanized and void of magic. Both poles have certain advantages and disadvantages. The pole nothing is more efficient, cheaper, and attracts a wider public. The pole something offers more pleasure, but is more expensive, attracts fewer people, who are nevertheless more faithful. Unlike a hospitable restaurant that lures you to linger at the table, fast-foods do their utmost to avoid this. The optimum situation for these is the 'drive-through' system, by which clients no longer enter the restaurant. Thus, inside fast-foods we see uncomfortable chairs, gaudy colours and an austere surrounding which are meant to make people not hang around too long, but continue on their way, allowing others to take their place. In the author's opinion, gaudy colours become more and more tiring as you stay longer.

Strident colours are spectacular, and the spectacular character is a characteristic of the non-place that helps the fluxes of people to keep on moving (Ritzer, 2010 [2007] and Barrico, 2010 [2006]). It was initially present in commercial spaces based on consumerism (fast-foods, malls, retail companies), becoming a model adopted in other areas of human existence. Between spectacular character and movement, G. Ritzer perceives visual fatigue, which does not allow you to linger. Alessandro Barrico has another complementary explanation: the facility to watch the spectacular character while being on the move. For the Italian philosopher, the spectacular character is shallow, while beauty needs effort, both in the phase of creation and in that of consuming it. Another component of the spectacular character is the difference. No longer believing in progress, people stop seeking a better fashion, and are content with a different fashion.

Young (2001) shows the importance of colours in the field of material culture through the analysis on a population of aborigines from Australia (Ernabella community). The researcher tried to see the concrete everyday life in the colours that were being used, and not the idealized symbolic projection of things beyond them. Doubtless the colours also play this role, but the attention of her research was directed towards the role of colours as social 
agents in the structuring of areas such as human body, space, emotions, social experiences, and processes of remembering anew and of transmitting information. Colours are used to create luminosity, space, to evoke temporality and to construct the identity. In her vision, colours are not to be understood as nuances, but as social relationships between certain objects and other objects, between certain people and other people, between objects and people.

The present research remains open together with the evolution of colours and of their significance in the context of house decoration. In this manner, we may check whether we will witness a decrease in the intensity and quantity of flashy colours or whether, on the contrary, these will follow a different direction.

\section{Conclusions}

Most traditional houses from the two areas of study used to display the colour of wood or were painted white. At present, local inhabitants prefer saturated colours such as orange, yellow, red, pink, green, blue or violet. I consider this change occurred under the impact the globalization had on the local environment, a phenomenon that disseminates non-places on the planet. Homogenization, the spectacular character and the shifts of fluxes of people (mass migration and / or tourism) are features of modernity making their presence felt more and more throughout the country.

Modernity is successful and attractive due to the comfort it brings to everyday life. For locals, it stands for prosperity, affluence, abundance, and wealth. It is associated with capitalism, where the economic offer on the market is extremely varied. From this varied offer, the local inhabitants have chosen some of the flashiest colours in order to regain access to a period of the past when they were denied contact with this market. At the same time, they wanted to show they are modern people, and not 'country peasants.'

In the 1990's, when the visits of tourists became more and more frequent, and these tourists demanded to see a traditional way of life, an inner conflict was stirred in the local inhabitants. The locals liked the idea of practising tourist activities just like in the mountain resorts, as this involves modern pastimes. But the idea of practising rural tourism did not appeal to them. For them, rural tourism means that the tourists are modern, the locals traditional, and whatever is modern is in a position of superiority. This is something they find as unacceptable. As I could figure out from the interactions that I had with them, locals like to be treated on an equal footing. As a consequence, they want to be as modern as the tourists from the urban environment or as the people who come from Western Europe. They preserve or revitalize any traditional object in the way they think a modern would: like a sort of museum.

Combining the traditional with the modern in a successful manner for the sake of the tourists constitutes a problem of ability, since this quality is not easy to acquire. The difficult effort of teaching and learning is acknowledged by the artists and architects who try to take part in this process of educating the tastes of the 
local inhabitants. This lends credit to A. Barrico's idea that beauty requires effort. The great stumbling block of this effort is that modern people hurriedly launch themselves into multiple experiences and activities, and lack the time to dedicate more thorough energy to any of these. A solution to this problem is suggested by the same Italian author. If one wishes to change the direction of things, one must bear in mind the criteria of mass culture (speed, efficiency, great quantity, cheap, easy, an effort as small as possible) and create better models on these very criteria, not on criteria that belong to the past. It is only in this way that new models of homes may become popular.

\section{References}

Augé, M. (1997 [1995]). Non-places. Introduction to an Anthropology of Supermodernity. London. New York: Verso. Barrico, A. (2010 [2006]). Barbarii. Eseu despre mutație [Barbarians. Essay on Mutation]. Bucharest. Humanitas.

Benthall, J. (1988). The Anthropology of Tourism. Anthropology Today, 4(3): 2022.

Buckley, R., Ollenburg, C. and Zhong, L. (2008). Cultural Landscape in Mongolian Tourism. Annals of tourism research, 35(1): 47-61.

Cawley, M. and Gillmor, D. A. (2008). Integrated Rural Tourism: Concepts and Practice. Annals of tourism research, 35(2): 316-337.

Castells, M. (2010 [1996]). The Rise of the Network Society. West Sussex: WileyBlackwell.

Cohen, E. (1984). The Sociology of Tourism: Approaches, Issues, and Findings. Annual review of sociology, 10: 373-392.

Giddens, A. (2000 [1990]). Consecințele modernității [The Consequences of Modernity]. Bucharest. Univers.

Mihăilescu, V. (2011). Zoom urban. Dilema veche [Urban Zoom, in the weekly entitled 'The Old Dilemma'], 368.

Mihăilescu, V. (2005). Între stil şi brand. Turismul alternativ la 2 Mai - Vama Veche. Societatea reală [Between Style and Brand. Alternative Tourism in the 2 Mai-Vama Veche resorts. Real Society] (Volume 3). Bucharest: Editura Paideia. Ordinul arhitectilor din Romania - filiala Transilvania [Order of Architects in Romania - Transylvanian Branch] (2009). Ghid de conversație pentru păstrarea specificului local. Studiu de caz Platoul Ghețari, comuna Gârda de Sus. [Phrase Book for the Maintenance of the Local Specific Character. Case Study: the Plateau of Ghețari, Commune of Gârda de Sus]. Alba Iulia: Altip.

Ordinul arhitectilor din Romania - filiala Nord Est [Order of Architects in Romania - North East Branch] (2011). Bucovina - un peisaj cultural în transformare. [Bucovina - A Cultural Landscape Undergoing Transformation]. Bucharest: 
Humanitas.

Relph, E. (1976). Place and Placelessness. London: Pion.

Ritzer, G. (2010 [2007]). Globalizarea nimicului. [The Globalization of Nothing].

Bucharest: Humanitas.

Ritzer, G. (2003 [2000]). Mcdonaldizarea societății. [The McDonaldization of

Society]. Bucharest: communicare.ro

Saunders, B. 2000. Revisiting Color Basic Term. The Journal of the Royal

Anthropological Institute, 6(1): 81-99.

Saunders, B. 2007. Towards a new topology of color. In Robert E. MacLaury,

Galina V. Paramei, Don Dedrick (coord.). Anthropology of Color, 467-479.

Amsterdam / Philadelphia: John Benjamins Publishing Company.

Seamon, D. and Sower, J. (2008). Place and Placelessness, Edward Relph. In P.

Hubbard, R. Kitchen, and G. Vallentine (ed.) Key Texts in Human Geography, 43-

51. London: Sage.

Stronza, A. (2001). Anthropology of Tourism: Forging New Ground for Ecotourism and Other Alternatives. Annual review of anthropology, 30: 261-283.

Young, D. J. B. (2001). The Color of Things. Memory, Materiality and an Anthropology of the Senses in North Western South Australia. London: University College. 